\title{
Media policy in Greenland
}

\section{Signe Ravn-Højgaard}

Department of Social Sciences, Economics and Journalism, University of Greenland \& Department of Communication and Arts, Roskilde University, Denmark

\begin{abstract}
This article describes the historical development of media policy in Greenland, and the shifts in the underlying normative and causal ideas that legitimise media policy. I argue that media policy reflects changes in Greenland's political system. Specifically, under colonial rule, Greenlandic media was state run and media was seen as an instrument to educate the population. Gradually, with the introduction of home rule, a paradigm shift took place, whereby media was seen as a vital instrument to strengthen Greenlandic language and identity. At the same time, normative ideas of media independence appeared which called for institutionalisation of the arm's length principle. Due to the influence and institutional spill-over from Denmark, I argue, Greenlandic media policy fit rather well into the "Nordic media model" although media policy in Greenland is mostly formulated without long-term or broad political agreements.
\end{abstract}

Keywords: Greenland, media policy, policy paradigms, Nordic media welfare state, media history

\section{Introduction}

Nordic media systems are marked by active government regulation and are often placed in a category of their own in comparative studies (Brüggemann et al., 2014; Syvertsen et al., 2014); however, these studies include only the larger Nordic states. Only few studies have focused on the Greenlandic media system in general (in particular, Hussain, 2019) while Greenlandic media policy has been left largely unstudied. To fill this gap and to understand whether Greenlandic media policy can be categorised as Nordic, this article answers the following two-fold question: Which policy paradigms are embedded in the Greenlandic media policy and how do they change over time? To answer this question, I go back to when the first newspaper was published in Greenland in 1861. I then track Greenlandic media policy development and analyse how policy can be understood in light of the changes that have taken place in the political system of Greenland.

Greenlandic media policy is an interesting object of study in itself, as media policy regulates the interplay between political systems and media systems (Hallin \& Mancini, 2004). Specifically, media policy moulds the public sphere in democratic societies (Napoli, 1999). Media policy can thus be a useful lens through which insights can

Ravn-Højgaard, S. (2021). Media policy in Greenland. Nordicom Review, 42(S2), 36-52. https:// doi.org/10.2478/nor-2021-0016 
be gained into how the relations between state, society, and media in Greenland have developed and changed over time. Greenlandic media policy is also an interesting case for theory testing, specifically, exploring whether the media welfare state ideal can be extended to include Greenland, a Nordic micro-society and self-governing territory.

I begin by outlining the central analytical concepts: policy paradigms, the analytical framework, and data used. Then media policy development is analysed followed by a discussion of which policy paradigms can be found in media policy. Lastly, I discuss how Greenlandic media policy fits into the Nordic Welfare state model developed by Syvertsen and colleagues (2014).

\section{Media policy paradigms}

Media policy can be regarded as a subfield within information policy that relates to "those technologies, processes and content by which the public itself is mediated" (Braman, 2004: 153). In this article, I employ Des Freedman's (2008: 14) definition of media policy: "Media policy refers to the development of goals and norms leading to the creation of instruments that are designed to shape the structure and behaviour of media systems". Media policies are embedded in and radiate underlying, abstract policy paradigms that define the problems to be solved by these policies (Schmidt, 2008). Policy paradigms, in turn,

[give] an overarching set of ideas that specify how the problems are to be perceived, which goals might be attained through the policies and what sorts of techniques can be used to reach those goals. [...] They structure the way in which policy-makers see the world and their role within. (Hall, 1992: 91-92)

Policy paradigms contain normative and causal ideas that play an important role in explaining media policy and its guiding principles. To be persuasive, a logic must contain both (Hall, 1993; Künzler, 2012; Schmidt, 2008). Normative ideas are perceptions of how the world should be (Schmidt 2008). These ideas serve to legitimise political action by appealing to the ideas and values of society to gain legitimacy. Causal ideas are conceptions about the mechanisms at play in the field and about which methods are needed to solve problems. Thereby, causal ideas justify political action by offering effective solutions to policy problems.

By examining the policy paradigms embedded in the Greenlandic media policy, I attempt to uncover the logics and normative assumptions about the media and democracy represented in media policy and describe how the role of media and the relationship between the state, society, and media have changed over time.

\section{Data and analytical framework}

Media policy differs from other policy areas (Puppis, 2014) as "media not only disseminate the decisions of policymakers, but are also active in shaping public policy and the ideas and decisions of policymakers" (Ali \& Puppis, 2018: 285). Hence, in this article I utilise a constructivist institutionalist approach, sensitive to relations of power, focusing on how policy is legitimised (Ali \& Puppis, 2018). In this constructivist institutionalist approach, "documentary research is seen as a tool for analysing the value-laden as- 
sumptions behind policy-making" (Karppinen \& Moe, 2012: 187), and the document analysis will therefore include a wide range of texts such as speeches, media coverage, and parliamentary debates (Karppinen \& Moe, 2019). Data collection has been done primarily through archival research, with the following types of documents: ${ }^{1}$

- Greenlandic newspaper articles from 1861-2019 and to a limited extent, radio and television news;

- resumés of parliamentary debates of the National Council (1911-1979) and the Greenlandic Parliament (1979-present);

- minutes of parliamentary debates in the Danish Parliament (pre-1980, when the media sector was the responsibility of the Danish state) as well as official reports from the colonial government in Greenland;

- laws and whitepapers from the abovementioned institutions;

- speeches by governors and ministers;

- and media reports and official inquiries on the media.

\section{Periodisation}

Although many historic media policy analyses have been structured around technological development of media (e.g., Bar \& Sandvig, 2008; Just \& Puppis, 2012; van Cuilenburg \& McQuail, 2003), this article takes another approach. While acknowledging the technological changes that impact policy, I structure the analysis around the changes in the political system in Greenland. Due to the historic dominant position of the government and the correspondingly small market and private sector, the government (whether Danish administration or Home Rule Government) has always played a pivotal role in the Greenlandic media system (Ravn-Højgaard, 2019). For this reason, the analysis is divided into three periods based on specific changes in the political system: the colonial period (1861-1953), county period (1953-1979), and home rule period (1979-).

Although colonisation of Greenland started before 1861, this year is chosen as a starting point for this analysis as it the year the first newspaper was published. Until 1953, Greenland had colonial status and was governed first by the Danish administrators of Kongelig Grønlandsk Handel [Royal Greenlandic Trade], and later by local Danish administrators employed by the state agency Grønlands Styrelse [Greenland Agency]. Over time, Greenlandic influence on the administration grew; particularly so after the 1911 establishment of two advisory councils (Rud, 2017). These councils were headed by the local Danish governor, and locally appointed Greenlanders had an advisory role regarding policy-making.

With the revision of the Danish constitution in 1953, Greenland became a county within the Kingdom of Denmark. The legislative power was therefore held by the Danish Parliament to which two representatives from Greenland were now elected. The executive power in Greenland was held by the Danish Government and was represented in Greenland by the local governor, who was a Danish civil servant. The governor headed the advisory council of locally elected Greenlanders, called Landsrådet [the National Council].

In 1979, home rule was introduced in Greenland. Responsibility was gradually transferred from Denmark to the newly established Greenlandic Home Rule Government 
(Self-Government from 2009). Media regulation was among the first sectors the Home Rule Government chose to take over (in 1980).

\section{Media policy in the colonial period, 1861-1953}

Access to media in Greenland was sparse before World War II (see Taagholt, 2012). The first Greenlandic newspaper, Atuagagdliutit, was started by the administrator of South Greenland, H. J. Rink, in 1861 to preserve Greenlandic tales and oral culture (Langgård, 1998). According to Rud (2010), the purpose of the newspaper was also to spread certain desired norms among Greenlanders. The Danish administrator approved all manuscripts before printing (Fleischer, 1980). Until the 1920s, the newspaper was only distributed once a year along the coast due to lack of infrastructure. The National Council regarded the newspaper as an important instrument for providing people "access to reading material" (National Council, 1930: item 14). The underlying normative idea was that newspapers were a means to enlighten and educate citizens, rather than a means to get access to news or engage in political debate. Atuagagdliutit was thus seen as a public good and was consequently distributed to households free of charge, funded entirely by the Danish state.

The political discussions on media policy were grounded in the normative argument that media's enlightening or instructional effect should be strengthened. Rud (2017) argues that similar normative ideas were reflected in much colonial policy at the time. In media policy, this was seen when the National Council discussed whether a higher frequency of the paper would have a larger "educating effect" (National Council, 1930: item 14) and the normative idea of universal access legitimised full state funding and direct state involvement in the media. From 1927, civil servants of the Greenland Agency in Copenhagen started writing and telegraphing news summaries to Greenland, where they were translated and posted on the notice boards of trading stations and sent out to the settlements (Sørensen, 2007; Taagholt, 2012). Atuagagdliutit was micro-managed by the National Council; for example, the council decided the editorial line, the paper quality, and the number of pictures in the paper. This exemplifies how media policy was case-by-case based, with policy solutions addressing specific problems. According to van Cuilenburg and McQuail (2003), such micro-managing was a common characteristic of early media policy.

\section{Media policy during the county period, 1953-1979}

During World War II, all communication between Greenland and Denmark was cut off. In 1942, due to this lack of news and information from Denmark, the administrator of Greenland initiated the Danish-language newspaper, Grønlandsposten. In 1951, the National Council unanimously decided to merge Grønlandsposten and Atuagagdliutit into a dual-language newspaper, $A / G$. Reflecting the ideas prevalent in Danish policies on Greenland at the time (Heinrich, 2017), it was argued that "it would improve understanding between Greenlandic and Danish ways of thinking and the exchange of ideas among the peoples" (National Council 1951: item 18-19; see also A/G, 1952). Augo Lynge, a prominent member of the National Council, argued that the newspaper was vital for cultural and moral development of the Greenlandic population, and the 
"lack of newspapers is one of the reasons why Greenland is underdeveloped" (National Council 1952: item 49). His statement reflects the normative idea whereby the media should educate people and the causal idea that providing access to media was the way to achieve this goal. $A / G$ was still supported economically by the Danish authorities and micro-managed by the National Council (National Council 1952: item 49); independent media was not a goal of media policy at the time. The journalist Benthien (2018) recalls that as late as 1967, the governor of Greenland had to approve news stories before they were published.

Grønlands Radio (GR) was founded in 1958 in order to improve and institutionalise the radio transmission started by the editors of Grønlandsposten and Atuagagdliutit during World War II. GR was a state institution under the Ministry of Greenland in Copenhagen, fully state-funded and mirroring the public Danish broadcaster Danmarks Radio (DR). The majority of GR's programmes were re-transmissions from DR, provided free of charge. No licence fee was paid by the users, and to date, one has never been introduced. The normative idea embedded in this policy was to enlighten the Greenlandic population, and the causal idea was that this could be achieved by providing access to information. In order to ensure access to the broadcasts, community houses were built all over Greenland, as radio receivers were not common (Taagholt, 2012). Likewise, the National Council found it important to translate the news from Denmark into Greenlandic so it could reach a larger audience. The council expected that "well-educated idealistic Greenlanders would do the translations voluntarily" (National Council, 1952: item 49).

When it came to television, DR held a legal monopoly on terrestrial television transmission in the entire Kingdom of Denmark, but DR did not air in Greenland. However, as the law did not restrict television transmission via cable, private entrepreneurs started broadcasting over closed cable networks (Radio Commission, 1970; TV Commission, 1975). By 1974, private cable-TV associations had been established and were transmitting television in 15 towns and settlements (TV Commission, 1975). In 1974, almost two-thirds of the households in Nuuk were members of the local association.

DR did not permit the television associations to use DR's broadcasts. Instead, the associations relied on individuals in Denmark to illegally tape programmes at home and send the tapes to each association (e.g., Pécseli, 1980; Rygaard, 2004, 2016 for a history of the television associations). Although illegal, this practice became institutionalised. For example, the Nuuk television association's weekly programme was printed in $A / G$. As the practice of broadcasting foreign production was illegal, it was not regulated, for instance, no requirements on subtitles or dubbing existed.

Eventually, policy-makers decided that illegal taping could not continue, and the Greenlandic TV Commission was formed by the Danish Parliament in 1971 to identify the most desirable way to introduce and organise television in Greenland. The commission published a whitepaper in 1975 suggesting that GR should be the central agency distributing tapes to the associations, where GR's content would primarily be DR rebroadcasts - now legalised and paid for by GR (TV commission, 1975). Most of the debate about television in Greenland during this period evolved around the economic and technical aspects and the legalisation of the usage of DR, leaving out political debates about social and cultural aspects of introducing television.

However, before a television infrastructure was rolled out, two things happened. First, the technological development of the radio chain in western Greenland made a model 
of terrestrial synchronous television possible in many areas. Synchronous television meant that the towns connected via the radio chain would receive the same broadcasts at the same time. Second, implementation coincided with the preparation of the Greenlandic home rule, where a new media policy paradigm appeared. This paradigm was in concordance with the general change in society, in which Greenlandic media was seen as an important tool for strengthening and vitalising Greenlandic language and culture (e.g., A/G, 1976). As a consequence, a model of synchronous television was implemented where GR broadcasted terrestrial signal to the television associations.

With the introduction of home rule, the normative role of media in society changed. Media was previously regarded as a venue for intercultural understanding among Greenlanders and Danes in Greenland, and as a means for Greenlanders to learn Danish. The new paradigm in media policy emerged with the normative ideas of media as a vital venue for preserving Greenlandic identity and minimising foreign influence. For example, as formulated by the Greenlandic TV Commission (1975: 37):

Transmission of Danish TV-programmes to Greenlandic screens without any kind of language editing would not be reconcilable with the general perception today, which focusses on preservation of the Greenlandic identity, strengthening of Greenlandic self-determination and reduction of Danish influence.

\section{Media policy in the home rule period, 1979-}

The new Home Rule Government took over responsibility for the media sector in 1980 . Grønlands Radio was renamed Kalaallit Nunaata Radioa (KNR) and was owned and funded by the government. In 1982, KNR started broadcasting television. The local television associations had to pay a fee to KNR to receive the synchronous television signal (or shipped tapes), while KNR paid copyrights to DR. Over the years, this fee led to conflicts between the television associations and KNR and the government. When associations had difficulties paying the fee, KNR threatened to close the signal (A/G, 1984a; Møller, 1986). Hence, in 1987, the Parliament of Greenland made KNR's signal freely available for all, regardless of whether they were members of a television association. The causal argument for this was that it would free up resources in the local television associations to produce more local content now that the associations did not have to pay the fee (Media Commission, 1984; A/G, 1984b). The television associations, on the other hand, believed that it took away their business, as membership of a television association was no longer required to watch KNR. This meant that the television associations had to look for other sources of income, which resulted in them pressing for legalisation of bingo, satellite-TV, and commercials. The Parliament of Greenland legalised all three, initially for a three-year test period (Greenland Home Rule Government, 1989). Jonathan Motzfeldt, premier and responsible for media, argued that these income-generating activities would increase the production of Greenlandic content in Greenlandic (A/G, 1988b). The underlying normative idea was the more television produced in Greenlandic, the better.

Over the years, these commercial activities led to friction between private media and KNR and the Home Rule Government. The private media saw the policy as a zero-sum game where commercials and bingo in KNR, or centralisation of satellite-TV 
distribution, would mean less revenue for private media (e.g., A/G, 1996; Brønden, 1996; Lyberth, 1991). Although discussed in the parliament, KNR was never allowed to air bingo and satellite-TV; however, advertisement on television is allowed. ${ }^{2}$ With the technological development, competition in bingo grew and the television associations' revenue dropped. Since KNR started broadcasting in 1982, most local television associations have closed down. Today, satellite distribution is the main business for the few still-existing associations. Very little local content is produced, although it is encouraged; for example, the public service contract requires KNR to buy a certain amount of locally produced content (Government of Greenland, 2019).

Around the time of the introduction of home rule, media independence started to appear as a normative goal in media policy and was supported by a causal logic to institutionalise the arm's length principle which, according to Moe and Mjøs (2013: 78), "entails outsourcing of both the decisions and the contracting of a services, such as cultural activities" by the government. An example of this is when the home rule minister of cultural affairs' chairmanship of KNR's board raised concern among parliamentarians, who feared the government would have too much control over KNR (Greenland Home Rule Whitepaper, 1978; Parliament, 1979: item 18). It was thus decided that KNR should be governed by the Radio Agency, to which the different parties in the parliament appointed the members. Yet, it is questionable whether increased independence was achieved, as the home rule minister of cultural affairs was also the chairman of the Radio Agency (until 1982), and the Radio Agency and its programme committee played an active role in the day-to-day business of KNR, for example, by approving broadcasting plans. In 1990, the parliament replaced the Radio Agency with a board, arguing that having a board would increase efficiency (Parliament, 1990). The debate about institutionalising a distance between KNR and the political system has reappeared frequently since.

Although institutionalising distance between the media and the political system is a goal of Greenlandic media policy, it is not always apparent in practice. For example, the Home Rule Ministry of Cultural Affairs was responsible for employment in KNR until 1989, which meant that KNR was affected by government employment freezes (A/G, 1988c). KNR is bound by public collective salary agreements and the government housing system, which, according to KNR, means that KNR is affected by government housing shortages (KNR, 2012) and non-competitive salaries (Schultz-Nielsen, 2017), making it difficult to attract new employees. Despite public service contracts being long discussed as a way to increase independence of KNR (Parliament, 1990), they were only introduced in 2004 after performance contracts had been introduced in other sectors. Even so, KNR has been without a public service contract several times - the latest January-November 2019.

Requests for more financial independence have also been discussed as a way to strengthen the editorial independence of KNR. Nevertheless, the funds for KNR are allocated every year as part of the annual political finance bill negotiations. In line with Benson and colleagues' (2017) research on the autonomy of public broadcasters, this practice has been criticised for making KNR more susceptible to political interference (e.g., Media Commission, 2010), and examples exist of politicians threatening to cut funding to KNR because of their dissatisfaction with KNR's coverage of specific issues (e.g., Mølgaard, 2013). 
The system of covering $A / G$ 's deficits continued after the Home Rule Government took over responsibility for the media sector in 1980 . No official laws or statutes regulated this practice. Premier Thue Christiansen called the subsidies compensation for "informing the public about the work of the Greenlandic Parliament" (Parliament, 1981: 319). $A / G$ 's board was headed by a minister from the Home Rule Government, and $A / G$ had, in periods, been placed under direct economic administration by the government because of financial difficulties (Sermitsiaq, 1981).

The privately owned Nuuk-based newspaper Sermitsiaq did not receive financial support from the government. The paper had close ties to the government in other ways though, for example, the government provided offices in the government buildings (Danker, 2018).

In order to enhance $A / G$ 's independence, the Media Commission of 1984 recommended replacing the coverage of $A / G$ 's deficit with indirect subsidies, namely postage and paper subsidies. Only postage subsidies were introduced, and direct subsidies to $A / G$ were removed. Beginning in 1987 , the board was no longer politically appointed, which was "the healthiest for a newspaper that should be critical of the public", according to the head of the board, Lars-Emil Johansen (A/G, 1988a), who continued in that position until 1991, while member of parliament and leader of the Siumut party. This is an example of how the arm's length principle became increasingly institutionalised in media regulation, but not necessarily in practice. There are various accounts of close personal relations between journalists and politicians, and of politicians directly or indirectly seeking to influence the editorial line or even threatening to cut funds if media were being too critical (A/G, 1990; Fleischer, 1986; Lauritzen, 1990).

In 1993, the parliament unanimously decided to establish an independent media foundation as a response to the economic difficulties of the press. This foundation was entrusted the government-owned print house (Sydtryk) and publishing house (Atuakkiorfik). The purpose was to provide support for the written press by using the foundation's yields to offer subsidised printing rates, loans, or subsidies to $A / G$ and Sermitsiaq. The establishment of the media foundation rested on the normative idea that independence of the press from the political system was vital. The causal idea and common understanding in the parliament was that in a country with a small population and huge infrastructural challenges, support of the press was necessary (Parliament, 1993). In spite of this, the media foundation was short-lived and did not benefit the papers much, as it never generated the intended funds for the newspapers (Brønden, 1997).

In 2008-2009, without prior debate in the parliament, postage subsidies were abolished (Egede, 2009; Greenland Home Rule Government, 2007; Media Commission, 2010) (see Table 1 for an overview). Minister of Infrastructure Jens B. Frederiksen, argued that since the remote villages receive the newspapers too late, Internet-based news was preferable (Kleist, 2009).

The government also decided to move the majority of their job advertisements from the Greenlandic newspapers and websites to Denmark (Johannessen, 2011). In 2010, this led to cutbacks and the fusion of Sermitsiaq and $A / G$ into one media outlet, Sermitsiaq.AG (see Hussain, 2019; Media Commission, 2010). In response to the economic crisis that resulted from the reduction of advertisements and subsidies, the parliament decided to introduce interim support in 2010-2012 to Sermitsiaq.AG (Greenland SelfGovernment, 2010). This was done via the finance bill, without any other legislation. 
Without parliamentary discussion, this support was continued, now termed "permanent media support" in the finance bill (Greenland Self-Government, 2013). Regardless, only two years later, in 2014, support was not allocated to Sermitsiaq.AG, leading to a highly politicised controversy. The newspapers and opposition accused the premier of removing the funding as a punishment for the newspapers' critical articles about her (LøvschallWedel, 2014). In the following years, subsidies to print media changed several times until the first law regulating support to print was passed in 2016.

Greenlandic media policy has been characterised by sudden changes and lack of broad or long-term media agreements, which makes the support susceptible to sudden changes. The latest example of this susceptibility was in 2019, when the government proposed a revision to the Finance Bill including a 50 per cent cut in the media subsidies as part of general cutbacks (Greenland Self-Government, 2019). With no prior debate in the parliament about the cuts, it appeared two days before the Finance Bill was passed. ${ }^{3}$

Table 1 Timeline of subsidies to national print media, 1861-2019

\begin{tabular}{ll}
\hline $1861-1980$ & $\begin{array}{l}\text { A/G was supported by the Danish state; no rules or laws regulated this } \\
\text { practice. }\end{array}$ \\
A/G supported by the Home Rule Government; no rules or laws \\
regulated this. \\
Direct support was replaced by reduced postage rates for print \\
media. \\
Interim support for the "transformation of the media". \\
$2010-2012$ & The parliament calls the support in the finance bill permanent. \\
2013 & Media support detained. \\
2014 & First government statute on media support, providing project \\
2015 & support to print and web media (Greenland Self-Government, 2015). \\
& $\begin{array}{l}\text { New government statute providing project support to print and web media } \\
\text { along with operational support to print media (Greenland Self-Government, } \\
2016\end{array}$ \\
& $\begin{array}{l}\text { Last-minute change to the Finance Bill for 2020 halved media } \\
\text { support. }\end{array}$ \\
\hline
\end{tabular}

\section{Media convergence and media policy}

Although Internet consumption is growing in Greenland, it is still lower than in the neighbouring Nordic countries. In contrast, the consumption of radio and television is higher (Ravn-Højgaard et al., 2018). This means that changes - such as increasing media convergence that can be observed globally and changes the conditions for media regulation (van Cuilenburg \& Slaa, 1993) - are not as pronounced in Greenland (RavnHøjgaard, 2019).

Whereas media policy in the neighbouring Nordic countries has become less national and media-specific due to media convergence (Gripsrud \& Moe, 2010), this has not been the case in Greenland, where media policy is still developed through a sector-by-sector approach. For instance, the current media subsidies scheme (Parliament, 2016b) provides operational support to print media only. 
Hansen (2004: 172) argued that telecommunication and Internet policy in reality is decided by the monopoly company, Tele Greenland, "as Tele Greenland's capacity, competence, and knowledge by far surpasses that of the Home Rule Government [translated]". Telecommunication policy is consequently not discussed as part of media policy, despite the fact that the pricing policies of the government-owned tele-company influence media consumption (see Ravn-Højgaard 2019). The law granting Tele Greenland monopoly on most telecommunication services and infrastructure provision in Greenland gives the government the power to set requirements on things such as functionality or the minimum level of service to be provided (Parliament, 2017). The government has not used this power, arguing that it should keep arm's length from the stock-based corporation, resulting in very few political discussions on topics such as pricing or quality of the Internet.

Other policy areas are likewise not considered part of media policy, but influence the structural environment of the media due to the significance of the public sector in Greenland. For example, it could be argued that government advertisement policy is important for the media economy.

\section{Paradigms in Greenlandic media policy}

Based on the above analysis, I argue that the policy paradigms that have emerged in Greenlandic media policy have distinct ways of legitimising policy and reflect changes at the macro political level; namely, the transition from colonial rule to home rule.

During colonial rule (1861-1953), media was state run and there was no media policy as such. Rather, media regulation was case-by-case based, and ad hoc measures were enforced when needed. This often manifested in micro-management of the media. Measures were grounded in normative ideas whereby access to media should educate people. This was supported by a causal logic whereby this educational effect could be achieved by ensuring access to media, for example, by providing newspapers freely through state funding.

In the county period (1953-1979), the media was still regarded as an instrument for education and venue for mutual understanding among Greenlanders and Danes. Although the state played a prominent role in the media landscape, private media emerged in the 1970s with the television associations and the Nuuk-based newspaper Sermitsiaq. This introduced commercial logic to media policy as well as normative ideas such as freedom of press, supported by causal ideas whereby media independence could be achieved by institutionalising distance between the media and the political system. This argument legitimised increasing the autonomy of the government-owned newspaper $A / G$.

The practice of supporting print media economically also became increasingly institutionalised. In the colonial period, $A / G$ was owned and financed by the state, while during the county period, the government covered $A / G$ 's deficits. In the home rule period, this direct support was replaced by different forms of indirect support in order to increase distance between media and the political system. Later, print media was again supported directly with a fixed amount allocated in the finance bill. Only in 2015 did support for print media become codified by way of a statute that gave explicit criteria for support (Greenland Self-Government, 2015).In concordance with the development in Greenlandic society in general at the time leading up to home rule (1979-present), another paradigm emerged. In this new paradigm, media became regarded as a vital venue 
for preserving Greenlandic identity and minimising Danish influence. For example, in 1975, politician and later Premier Lars-Emil Johansen believed that the media should be solely in Greenlandic, and thereby "focused on Greenlandic needs and understandings" (Johansen, 1975: 18). Paradoxically, the underlying causal idea then was that in order to build the capacity to provide Greenlandic content in the long run, filling up the majority of the airtime with unedited and un-dubbed re-broadcasts from DR was a necessity (Parliament, 1983). Since the establishment of KNR, the aim has been to achieve 80 per cent of the programming in Greenlandic and 20 per cent in Danish (TV Commission, 1975). The parliamentarians, however, did not believe that the goal was achievable in the first years of Greenlandic television.

Whereas radio eventually reached the goal of 80 per cent of programming in Greenlandic, this was not the case with television. In 1989, only 5 per cent of television programming was broadcast in Greenlandic (KNR, 1990). The goal was only met when digitalisation of distribution enabled the transmission of several television channels. As it became technically possible, the government decided to transmit several DR channels along with KNR in 2012. This changed the composition of KNR's content, which now focused exclusively on Greenlandic content. This meant that DR re-broadcasts were excluded and total broadcasting hours reduced, which resulted in 89 per cent of KNR's content being in Greenlandic in 2018 (KNR, 2019).

Strengthening Greenlandic language by regulating or supporting Greenlandic language use in the media has been frequently discussed in the parliament and by the public (Kleemann-Andersen, 2020). For instance, a government-initiated Greenlandic-language paper was proposed in 1993 (Parliament, 1993), although it never materialised. Requirements for the media to use Greenlandic only have also been proposed (e.g., Parliament, 2016a), and lately, Vivian Motzfeldt, president of the parliament, suggested language requirements for online media (Rasmussen, 2020). These propositions were - especially by the private media - labelled government interference hampering media independence. Consequently, the implemented media regulation has often tried to balance the sometimes-conflicting normative goals in media policy: media independence and media as a means of strengthening Greenlandic language and culture. Today, the public broadcasting service contracts specify how many hours of television in Greenlandic (and Danish) KNR should produce, and, to receive subsidies, print media should be at least in Greenlandic (Parliament, 2016b).

\section{A Nordic media policy?}

Syvertsen and colleagues (2014) argue that media policy in the Nordic countries share four characteristics: 1) media is seen as a public good, 2) freedom from editorial interference is a policy goal, 3) media policy is conceived as central to cultural policy, and 4) media policy is developed through cooperative and consensual processes, which makes policy stable and durable. I argue here that the Greenlandic media system can, to a large extent, be said to fit into what Syvertsen and colleagues have labelled the media welfare state, except when it comes to stable and durable media policy.

Historically, in Scandinavia, the "public good" idea has been the argument for monopolising scarce resources and providing universal access (Syvertsen et al., 2014). In Greenland - which has few actors and little competition in the media market - the 
argument for monopolisation has only been to provide universal access in areas where access would be economically unfeasible.

The normative idea of distancing media from the political system has become more prominent over time in Greenlandic media policy. Hussain (2019: 118) found that "KNR historically has been seen as a channel for information, but a professionalisation and distance to the political system has taken place". This can be seen in the increasing institutionalisation of the arm's length principle in legislation. Thus, a normative idea of media independence has become more apparent in media policy in Greenland, although it is not always reflected in actual practices or regulation.

In line with what Syvertsen and colleagues (2014) stipulate, media policy in Greenland is a central part of cultural policy. It aims to secure diversity and quality media through subsidies and regulations in order "to modify the influence of market forces, thus countering the strong influx of standardised and global mass culture in the 20th century" (Syvertsen et al., 2014: 18). Recent Greenlandic media policy seeks to achieve sociopolitical goals characteristic of small media systems, such as language preservation (Puppis, 2009). Private media are not merely perceived as commercial companies, but also as a way to achieve sociopolitical policy goals, such as media diversity. Economic support for the private media should advance these goals.

Whereas the media welfare state, according to Syvertsen and colleagues (2014), has a preference for policy solutions that are durable and stable and involve consultation between all main stakeholders, this is rarely the case in Greenland. During the colonial period, media policy, like all other policy areas, was formulated largely by the technocratic colonial administration. Early media policy was based on ad hoc decisions, and there was no specific policy as such. With a change of regime, politicians and private media appeared and policy processes became increasingly more consensual. Even so, practices preceded policy. For instance, the private television associations had established distribution infrastructure before any regulation was in place. This meant that there was no language policy for television programming and that private associations came to own the distribution network for public service content. Although the Greenlandic media sector has become increasingly institutionalised and regulated during the home rule period, media policy is still formulated without long-term or broad political agreements. Constitutive political debates - or visions for media policy - have been few, and often focused on economy and technical aspects, and none of the political parties in parliament have formulated policies on media (as assessed in January 2020). Like many other countries (Just \& Puppis, 2012), media policy is considered low politics in Greenland, which means that media regulation in Greenland is often put in place suddenly to address a pressing problem on a case-by-case basis, without broad or long-term political media agreements. As a consequence, the instruments for regulating media have often been changed suddenly. The small scale of the political system in Greenland is an important factor in explaining the ad hoc approach to policy-making, as the small size makes it difficult to obtain a critical mass of politicians and civil servants to have substantial competence in a specific policy area. This can increase the danger of particularistic policy-making (Randma-Liiv, 2020).

Except when it comes to durable and consensual policy, I argue that Greenlandic media policy fits rather well into the Nordic media welfare state model. This can be largely explained by the fact that media policy in Greenland shares many similarities 
with Danish media policy, as many laws and directives are copies of Danish law, for example, the 2007 media liability act (Parliament, 2007). Further, the media sector was governed by the Danish government until 1980, and many civil servants, journalists, and professional norms have been imported from Denmark (Hussain, 2019).

\section{Conclusion}

In this article, I have argued that media policy paradigms in Greenland reflect the transformation of society and the political system, as the regime changed from a colony (1861-1953), to a county of Denmark (1953-1979), to a home rule region (1979-).

During the colonial period, media was owned and managed by the state. Normative ideas of media as a means to educate the population were embedded in media policy. These were supported by causal logics whereby the intended education could be achieved by ensuring access to media.

During the county period, this paradigm was gradually replaced by a new paradigm evolving around two normative ideas: media independence and media as a way to strengthen Greenlandic language and culture. The latter idea was supported by causal logics of language quotas and "necessary evils"; foreign-language television, satellite$\mathrm{TV}$, and advertisements were seen as necessities for funding Greenlandic content. Media independence was supported by the causal logic of the arm's length principle, for instance, by establishing an independent board of KNR so the governance of the Greenlandic public broadcasting service would become more independent of the political system.

In sum, modern Greenlandic media policy has come to share a lot of characteristics with Syvertsen and colleagues' (2014) media welfare state ideal. This can largely be explained by a substantial spill-over from Denmark. However, the small size of the Greenlandic media market makes it a less ideal fit to the ideal type. For example, practices have often emerged before regulation, as media policy in Greenland has been caseby-case based without the broad or long-term media agreements that are seen in other Nordic countries. Instead, media policy, considered low politics, is often addressed on an ad hoc basis to respond to a pressing problem. This makes policy volatile, as it can change quickly and create insecurity in the media market, not least since the government plays a large role in the Greenlandic media market.

\section{Notes}

1. All quotes originally in Greenlandic or Danish have been translated into English by the author.

2. In 2019, 4 per cent of KNRs revenue came from advertisement (KNR, 2020).

3. The municipalities have supported local media through different schemes. Historically, this has been done in return for influence in the media (Pesceli, 1980: 14). The government subsidied the local television and radio stations with DKK 1.9 million in 2018 (see Hussain in Ravn-Højgaard et al., 2018, for an overview).

\section{References}

A/G. (1952, January). To blade bliver til eet [Two newspapers become one]. $A / G, 1,3$.

A/G. (1976, August 26). Grønlandsk TV kan få katastrofal betydning [Greenlandic television can have a huge impact]. $A / G, 34,16$.

A/G. (1984a, April 17). TV-signalet blev alligevel ikke afbrudt [After all the TV signal was not cut]. $A / G$, 16,30 . 
A/G. (1984b, December 5). AG, Sermitsiak, aviisillu allat tamaasa pisariaqartippavut $[A / G$, Sermitsiaq and all the other newspapers er important for us]. $A / G, 49,27-29$.

A/G. (1988a, February 24). AG-ip siulersuisui amerlisut [More members of the board of A/G]. A/G, 10, 2.

A/G. (1988b, April 25). Pressen - leder [The press - editorial]. $A / G, 34,8$.

A/G. (1988c, August 31). Der spares på ytringsfriheden [Economising freedom of speech]. $A / G, 70$, appendix, 6-7.

A/G. (1990, October 24). Politikernes privatliv [The private life of the politicians]. $A / G, 123,10-11$.

A/G. (1996, February 29). Akileraarutit aviisinik ajortitsipput [Tax payers' money damage the newspapers]. $A / G, 17,1$.

Ali, C., \& Puppis, M. (2018). When the watchdog neither barks nor bites: Communication as a power resource in media policy and regulation. Communication Theory, 28(3), 270-291. https://doi.org/10.1093/ct/qtx003

Bar, F., \& Sandvig, C. (2008). US communication policy after convergence. Media, Culture and Society, 30(4), 531-550. https://doi.org/10.1177/0163443708091181

Benson, R., Powers, M., \& Neff, T. (2017). Public media autonomy and accountability: Best and worst policy practices in 12 leading democracies. International Journal of Communication, 11, 22.

Benthien, J. (2018, May 18). Naveersinneq siulleq [The first scolding]. Sermitsiaq, 20, 34-35.

Braman, S. (2004). Where has media policy gone? Defining the field in the twenty-first century. Communication Law and Policy, 9(2), 153-182. https://doi.org/10.1207/s15326926clp0902_1

Brønden J. (1996, September 24). KNR kan blive nødt til at opgive bingospillet [KNR might have to give up bingo]. $A / G, 77,11-12$.

Brønden, J. (1997, June 19). Aningaasaateqarfik aningaasaateqanngitsoq [The fund without funds]. A/G, 46, 4.

Brüggemann, M., Engesser, S., Büchel, F., Humprecht, E., \& Castro, L. (2014). Hallin and Mancini revisited: Four empirical types of western media systems. Journal of Communication, 64(6), 1037-1065. https:// doi.org/10.1111/jcom. 12127

Danker, P. (2018). Der var engang et lokalblad [Once upon a time there was a local paper]. Tidsskriftet Grønland, 4, 236-255.

Egede, E. (2009, September 8). Naalakkersuisut aviisit matutinniarpaat [Government wants to close down the newspapers]. $A / G, 64,5$.

Fleischer, J. (1980). Et grønlandsk blad-Atuagagdliutit 120 år [A Greenlandic paper-Atuagagdliutit 120 years]. Nuuk: Det grønlandske forlag.

Fleischer J. (1986, January 15). Et uafhcengigt AG - leder [An independent AG - editorial]. A/G, 3, 9.

Freedman, D. (2008). The politics of media policy. Cambridge: Polity.

Government of Greenland. (2019): Public service resultatkontrakt for perioden 1. januar 2019 til og med 31. december 2022 mellem KNR og Naalakkersuisut om omfang og indhold af KNRs public service forpligtelse [Public service result contract for the period 1 January 2019 till 31 December 2022 between KNR and the Government of Greenland about scope and content of KNR's public service obligation]. Naalakkersuisut.

Greenland Home Rule Government. (1989). Hjemmestyrets bekendtgørelse nr. 10 af 29. marts 1989 om cendring af bekendtgørelse $\mathrm{nr} .2$ af 27. januar 1981 om radio-og fjernsynskoncessioner til private eller offentlige sendeanlag i lokale områder i Grønland [Home Rule statute 10 of 29 March 1989 amendment to statute 2 of 27 January 1981 on radio and television concessions to private or public transmission stations within local areas in Greenland].

Greenland Home Rule Government. (2007). Landstingsfinanslov 2007 [Finance Bill 2007]. Grønlands Hjemmestyre.

Greenland Home Rule Whitepaper. (1978). Betcenkning afgivet af Kommissionen om Hjemmestyre i Grønland, april 1978, Betænkning nr. 837, København [Report submitted by the Commission on Home Rule in Greenland, April 1978, Report no. 837, Copenhagen].

Greenland Self-Government. (2010). Finanslov for 2010 [Finance Bill 2010]. Grønlands Selvstyre.

Greenland Self-Government. (2013). Finanslov for 2013 [Finance Bill 2013]. Grønlands Selvstyre.

Greenland Self-Government. (2015). Selvstyrets bekendtgørelse nr. 19 af 8. oktober 2015 om medietilskud [Self-Government statute number 19 of 8 October 2015 on media support].

Greenland Self-Government. (2016). Selvstyrets bekendtgørelse $\mathrm{nr} .10$ af 26. maj 2016 om driftstilskud til trykte landsdakkende medier [Self-Government statute number 10 of 26 May 2016 on operational support to national print media].

Greenland Self-Government. (2019). Forslag til tillagsbevillingslov for 2019 [Proposal for a supplementary appropriations law 2019]. Grønlands Selvstyre.

Gripsrud, J., \& Moe, H. (2010). The digital public sphere: Challenges for media policy. Gothenburg: Nordicom, University of Gothenburg.

Hall, P. A. (1992). The movement from Keynesianism to monetarism: Institutional analysis and British economic policy in the 1970 s. In S. Steinmo, K. Thelen, \& F. Longstreth (Eds.), Structuring politics: 
Historical institutionalism in comparative anlysis (pp. 90-113). Cambridge: Cambridge University Press. https://doi.org/10.1017/cbo9780511528125.005

Hall, P. A. (1993). Policy paradigms, social learning, and the state: The case of economic policymaking in Britain. Comparative Politics, 25(3), 275-296. https://doi.org/10.2307/422246

Hallin, D. C., \& Mancini, P. (2004). Comparing media systems: Three models of media and politics. Cambridge: Cambridge University Press. https://doi.org/10.1017/CBO9780511790867

Hansen, K. G. (2004). IT-sektoren i et magtperspektiv [The IT sector in a power perspective]. In G. Winther (Ed.), Demokrati og magt i Grønland [Democracy and power in Greenland] (pp. 162-194). Aarhus: Aarhus University Press.

Heinrich, J. (2017). Krig og afkolonisering 1939-53 [War and decolonisation 1939-53]. In H. C. Gulløv (Ed.), Grønland den arktiske koloni [Greenland the Arctic colony] (pp. 282-319). Copenhagen: Gads Forlag.

Hussain, N. (2019). Journalistik i små samfund: Et studie af journalistisk praksis på grønlandske nyhedsmedier [Journalism in small societies: a study of journalistic practice in Greenlandic news media] [Doctoral thesis, Roskilde University, Denmark].

Johannessen S. U. (2011, February 8). Annoncer kunne have afværget avisfusion [Newspaper fusion could have been hindered by advertisement]. Sermitsiaq, 7, 6 .

Johansen, L. E. (1975, March 13). Dobbeltsprogethed et handikap for kommunikationen [Bilingualism is a disadvantage for communication]. Atuagagdliutit, 11, 18.

Just, N., \& Puppis, M. (2012). Communication policy research: Looking back, moving forward. In Trends in communiation policy research: New theories, methods and subjects (pp. 11-29). Bristol: Intellect Books.

Karppinen, K., \& Moe, H. (2012). What we talk about when we talk about document analysis. In N. Just, \& M. Puppis (Eds.), Trends in communication policy research: New theories, methods and subjects (pp. 360-379). Bristol: Intellect Books.

Karppinen, K., \& Moe, H. (2019). Texts as data I: Document analysis. In H. van den Bulck, M. Puppis, K. Donders, \& L. van Audenhove (Eds.), The Palgrave handbook of methods for media policy research (pp. 249-262). Cham, Switzerland: Palgrave Macmillan. https://doi.org/10.1007/978-3-030-16065-4

Kleemann-Andersen, C. (2020). Plastikblomster og tungeløse grønlcendere [Plastic flowers and Greenlanders without language] [Master's thesis, Ilisimatusarfik, Greenland]. https://uni.gl/media/5987234/slmspeciale-plastikblomster-og-tungeloese-groenlaendere.pdf

Kleist, P. (2009, September 29). Aviserne må rationalisere [The newspapers should rationalise their business]. $A / G, 70,6-7$,

KNR. (1990). KNR's årsrapport for 1989 [KNR's annual report 1989]. Nuuk: KNR.

KNR. (2012). KNR's årsrapport for 2011 [KNR's annual report 2011]. Nuuk: Deloitte.

KNR. (2019). KNR Public service redegørelsen 2018 [KNR public broadcasting service inquiry 2018]. Nuuk: KNR.

KNR. (2020). KNR's årsrapport for 2019 [KNR annual report 2019]. Nuuk: Deloitte.

Künzler, M. (2012). It's the idea, stupid! How ideas challenge broadcasting liberalization. In M. Puppis, \& N. Just (Eds.), Trends in communication policy research (pp. 57-74). Bristol: Intellect Books.

Langgård, K. (1998). An examination of Greenlandic awareness of ethnicity and national self-consciousness through texts produced by Greenlanders 1860s-1920s. Etudes Inuit, 22(1), 83-107.

Lauritzen, P. (1990, October 12) Asasara Juntaaq! [Dear Jonathan!]. A/G, 118, 4-5.

Lyberth, J. (1991, October 21). Ilumut kiinaannguusaarnassaqaaq [Really embarrassing indeed]. $A / G, 121,5$.

Løvschall-Wedel, J. (2014, July 16). Aleqa trak avisstøtte på tvivlsomt grundlag [Aleqa removed newspaper support on questionable grounds]. KNR. Retrieved August 1, 2020, from https://knr.gl/da/nyheder/aleqatrak-avisst $\% \mathrm{c} 3 \% \mathrm{~b} 8 \mathrm{tte}-\mathrm{p} \% \mathrm{c} 3 \% \mathrm{a} 5$-tvivlsomt-grundlag

Media Commission. (1984). Betcenkning vedrørende radio- og tv-spredning i Grønland. Nuuk.

Media Commission. (2010). Stcerke medier - Redegørelse fra mediearbejdsgruppen nedsat af Naalakkersuisut [Strong Media - Whitepaper from the Media Commission appointed by the Government of Greenland]. Nuuk.

Moe, H., \& Mjøs, O. J. (2013). The arm's length principle in Nordic public broadcasting regulation. In U. Carlsson (Ed.), Public service media from a Nordic horizon: Politics, markets, programming, and users (pp. 75-92). Gothenburg: Nordicom, University of Gothenburg.

Mølgaard, N. (2013, June 5). Nikku: Brug for mere mediekontrol [Nikku: More media control is necessary]. Sermitsiaq.AG. https://sermitsiaq.ag/nikku-brug-mere-mediekontrol

Møller, S. (1986, July 16). Ilulissani suli TV-qanngilaq [Ilulissat still has no TV signal]. A/G, $29,5$.

Napoli, P. M. (1999). The unique nature of communications regulation: Evidence and implications for communications policy analysis. Journal of Broadcasting and Electronic Media, 43(4), 565-581. https:// doi.org/10.1080/08838159909364510

National Council. (1930). Landsrådets Forhandlinger 1930 [Proceedings of the National Council of Greenland, 1930]. In Beretninger og kundgørelser fra kolonierne i Grønland for Aarene 1928-1932 [Reports and announcements from the colonies in Greenland for the years 1928-1932]. Copenhagen: Grønlands Styrelse. 
National Council. (1951). Grønlands Landsråds Forhandlinger 1951 [Proceedings of the National Council of Greenland, 1952]. In Beretninger vedrørende Grønland, 2, Copenhagen: Grønlands Styrelse.

National Council (1952). Grønlands Landsråds Forhandlinger 1952 [Proceedings of the National Council of Greenland, 1952]. In Beretninger vedrørende Grønland, 3 [Reports concerning Greenland, 3]. Copenhagen: Grønlands Styrelse.

Parliament. (1979, spring). Grønlands Landstings forhandlinger, forår 1979 [Proceedings of the Greenlandic Parliament, spring 1979]. Nuuk: Greenland Home Rule Government.

Parliament. (1981, spring). Grønlands Landstings forhandlinger, forår 1981 [Proceedings of the Greenlandic Parliament, spring 1981]. Nuuk: Greenland Home Rule Government.

Parliament. (1983, fall). Grønlands Landstings forhandlinger, efterår 1983 [Proceedings of the Greenlandic Parliament, fall 1983]. Nuuk: Greenland Home Rule Government.

Parliament. (1990, spring). Grønlands Landstings forhandlinger, forår 1990 [Proceedings of the Greenlandic Parliament, spring 1990]. Nuuk: Greenland Home Rule Government.

Parliament. (1993, spring). Grønlands Landstings forhandlinger, forår 1993 [Proceedings of the Greenlandic Parliament, spring 1993]. Nuuk: Greenland Home Rule Government. https://ina.gl/glsamlinger/samlinger/FM-1993/Dagsordenens\%20punkt\%2031-1.htm

Parliament. (2007). Landstingslov nr. 17 af 19. november 2007 om medieansvar [Parliament act no. 17 of 19 November 2007 on media liability].

Parliament. (2016a, fall). Inatsisartutforhandlinger, efterår 2016 [Proceedings of the Greenlandic Parliament, fall 2016]. Nuuk: Greenland Home Rule Government. https://ina.gl/samlinger/oversigt-over-samlinger/ samling/punktliste/

Parliament. (2016b, November 28). Inatsisartutlov $n r .20$ af 28. november 2016 om mediestøtte [Parliament law 20 of 28 November 2016 on media support]. Inatsisartut.

Parliament. (2017, November 23). Inatsisartutlov nr. 31 af 23. november 2017 om telekommunikation og teletjenester [Parliament law 31 of 23 November 2017 on telecommunication and tele-services]. Inatsisartut.

Pécseli, B. (1980). Massemedier i Grønland [Mass media in Greenland]. Tidsskriftet Grønland, 1, 6-15.

Puppis, M. (2009). Media regulation in small states. International Communication Gazette, 71(1-2), 7-17. https://doi.org/10.1177/1748048508097927

Puppis, M. (2014). The regulation of political communication. In C. Reinemann (Ed.), Political Communication (pp. 39-62). Boston: De Gruyter Mouton. https://doi.org/10.1515/9783110238174.39

Radio Commission. (1970). Betcenkning af radiokommission nedsat den 15. juni 1967 af Ministeriet for Kulturelle Anliggender [Whitepaper by the Radio Commission appointed on 15 June 1967 by the Ministry of Cultural Affairs]. Betænkning nr. 592 [Report number 592]. Copenhagen.

Randma-Liiv, T. (2020). Small states: Public management and policy-making. In G. Baldacchino, \& A. Wivel (Eds.), Handbook on the politics of small states (pp. 55-69). Cheltenham, UK: Edward Elgar Publishing.

Rasmussen I. S. (2020, August 17). Grønlandsk skal være magtsproget [Greenland will be the language of power]. $A / G, 25,12-15$.

Ravn-Højgaard, S. (2019). Medier og selvstændighed i Grønland [Media and independence in Greenland]. Politik, 22(1), 67-83. https://doi.org/https://doi.org/10.7146/politik.v22i1.114841

Ravn-Højgaard, S., Paulsen, N., Willig, I., Hussain, N., \& Simonsen, M. (2018). Tusagassiuutit - En kortlogning af de grønlandske medier [Mapping of Greenlandic media]. Nuuk: University of Greenland.

Rud, S. (2010). Subjektiveringsprocesser i metropol og koloni, København og Grønland i 1800-tallet [Processes of subjectivisation in metropol and colony, Copenhagen and Greenland in the 19th century] [Doctoral thesis, University of Copenhagen, Denmark].

Rud, S. (2017). Grønland til debat 1905-19 [Debating Greenland 1905-19]. In H. C. Gulløv (Ed.), Grønland den arktiske koloni [Greenland the Arctic colony] (pp. 238-280). Copenhagen: Gads Forlag.

Rygaard, J. (2004). En tv-historie [A history of television]. In B. Jacobsen (Ed.), Grønlander og global: grønlandsk sprog, litteratur og medier i 25-året for Hjemmestyrets indførelse [Greenlander and global: Greenlandic language, literature, and media in the 25th anniversary of the introduction of the Home Rule Government]. Nuuk: University of Greenland.

Rygaard, J. (2016). KNR - lille tv station blandt giganter: Udfordringer for TV og public service i Grønland [KNR - a small TV station among giants: Challenges for television and public service in Greenland]. In J. Fink, K. G. Hansen, \& O. Marquardt (Eds.), Grønland i Tal: Kilder og cases gennem 300 år [Greenland in Figures: Sources and cases through 300 years]. Aarhus: Aarhus University Press.

Schmidt, V. A. (2008). Discursive institutionalism: The explanatory power of ideas and discourse. Annual Review of Political Science, 11(1), 303-326. https://doi.org/10.1146/annurev.polisci.11.060606.135342

Schultz-Nielsen, J. (2017, November 1). Opråb fra journalist: Journalistikken er i fare [Call from a journalist: Journalism is endangered]. Sermitsiaq.AG. https://sermitsiaq.ag/node/201230

Sermitsiaq. (1981, January 16). Informationspligt [Duty of information]. Sermitsiaq, 3, p. 2. 
Syvertsen, T., Enli, G. S., Mjøs, O. J., \& Moe, H. (2014). The media welfare state: Nordic media in the digital era. Ann Arbor, Michigan: University of Michigan Press. https://www.doi.org/10.3998/ nmw.12367206.0001.001

Sørensen, A. K. (2007). Denmark-Greenland in the twentieth century (Vol. 341). Copenhagen: Commission for Scientific Research in Greenland. https://doi.org/10.26530/oapen_342354

Taagholt, J. (2012). Medier [Media]. In J. Taagholt, \& H. P. Steenfos (Ē̄s.), Grønlands teknologihistorie [Greenland's technology history] (pp. 431-438). Copenhagen: Gyldendal.

TV Commission. (1975). TV i Grønland, Betcenkning afgivet af det grønlandske TV-udvalg [Television in Greenland, Whitepaper by the Greenlandic TV Commission]. Betænkning nr. 739 [Report number 739]. Copenhagen.

van Cuilenburg, J., \& McQuail, D. (2003). Media policy paradigm shifts: Towards a new communications policy paradigm. European Journal of Communication, 18(2), 181-207. https://doi. org/10.1177/0267323103018002002

van Cuilenburg, J., \& Slaa, P. (1993). From media policy towards a national communication policy: Broadening the scope. European Journal of Communication, 8(2), 149-176. https://doi. org/10.1177/0267323193008002002

(C) 2021 Nordicom and respective authors. This is an Open Access work licensed under the terms of the Creative Commons Attribution-NonCommercial-NoDerivatives 4.0 International Public licence (CC BY-NC-ND 4.0). To view a copy of the licence, visit https://creativecommons.org/ licenses/by-nc-nd/4.0/ 